Князь, Тетяна. «Емоційно-оцінні фразеологізми української мови в політичному дискурсі». Лінгвостилістичні студї, вип. 11, 2019, с. 54-64.

Kniaz, Tetiana. "The Ukrainian Emotionally-Evaluative Phraseologisms in the Political Discourse". Linguostylistic Studies, iss. 11, 2019, pp. 54-64.

УдК 811.161.2'373.7

https://doi.org/10.29038/2413-0923-2019-11-54-64

\title{
ЕМОЦІЙНО-ОЦІННІ ФРАЗЕОЛОГІЗМИ УКРАЇНСЬКОЇ МОВИ В ПОЛІТИЧНОМУ ДИСКУРСІ
}

\author{
Тетяна Князь \\ Харківський національний аграрний університет ім. В.В. Докучаєва, \\ Харків, Україна
}

\begin{abstract}
У статті проаналізовано комунікативно-прагматичні особливості функціонування фразеологізмів як засобів вираження емоційно-оцінних висловлювань у політичному дискурсі. Розглянуто види структурно-семантичних трансформацій фразеологізмів: еліпсис, субституція, розширення компонентного складу. Емоційно-оцінні фразеологізми у політичному дискурсі слугують для здійснення ефективної комунікації, реалізуючи низку комунікативних функцій: повідомлення, експресії, впливу.

Ключові слова: фразеологічна одиниця, оцінне значення, політичний дискурс, структурно-семантична трансформація.

\section{THE UKRAINIAN EMOTIONALLY-EVALUATIVE PHRASEOLOGISMS IN THE POLITICAL DISCOURSE Tetiana Kniaz}

Kharkiv National Agrarian University named after V. V. Dokuchaiev, Kharkiv, Ukraine

Dominance of the cognitive-discursive paradigm in the linguistic studies allows answering a number of important scientific issues, such as identifying verbal and rhetorical strategies in the political discourse, revealing methods and regularities of verbalization of complex cognitive, psychological, mental, cultural, and historic categories. Modern approaches in linguistics facilitate the comprehensive study of function features of both traditional and transformed phraseological units in the political discourse. The new approaches rely on the latest findings in the adjacent branches of linguistics, like psycholinguistics, cognitive linguistics, pragmalinguistics. The abovementioned determines the relevance of the research.

The study seeks to identify and analyze the communicative, pragmatic, structural, and semantic characteristics of phraseologism functioning as a means of expressing emotionally evaluative statements in the political discourse.

The in-depth analysis of the linguistic facts, particularly the use of phraseological units with evaluative meaning, allows revealing the stereotypical models of the Ukrainian political reality perception. Political realities are often characterized by the use of phraseologisms expressing positive or negative attitude to the depicted event. The emotional-evaluative characteristics of phraseologisms in the political discourse provide a basis for effective

(C) Князь Т., Східноєвропейський національний університет імені Лесі Українки, 2019.

Це стаття відкритого доступу на умовах CC BY-NC 4.0 
communication, realizing a wide range of communicative functions: message, expression, influence, even the manipulation of human consciousness.

Phraseologisms reflect the evaluative features both implicitly and explicitly, which is impossible without the contextual environment in which the phraseologism functions. Political discourse is dominated by phraseologisms, the meaning of which reflects a disapproving evaluation, because they characterize situations where one gets rich or profane in some dishonest way, when one causes material damage, which leads to poverty of the population.

Key words: phraseological unit (PhU), evaluative meaning, political discourse, structural and semantic transformation.

Вступ. Домінування в мовознавстві когнітивно-дискурсивної парадигми зумовлює нові методи дослідження мови та її «текстоводискурсивних продуктів», дозволяє вирішення низки важливих наукових завдань: з'ясування вербальних і риторичних стратегій у політичній діяльності, виявлення способів і закономірностей вербалізації складних когнітивно-психологічних, ментальних, культурно-історичних категорій. Н. Арутюнова визначає дискурс як «зв'язний текст у сукупності 3 екстралінгвістичними, прагматичними, соціокультурними, психологічними та іншими чинниками» (136), як «мову, занурену в життя» (137). Суспільно-політичні тексти досліджують у зв'язку 3 їх появою й розвитком, і під час аналізу слід ураховувати всі соціальні, психологічні, культурологічні та прагматичні чинники.

Основним об'єктом когнітивної психології $€$ репрезентація знань зовнішнього світу в психіці людини, внутрішні структури й механізми оброблення знань. «Увібравши всю сукупність нагромаджених народом знань про суспільно-політичну дійсність, політична картина світу $є$ не тільки інформаційною базою нашого мислення, а й когнітивнопсихологічним «образом нас». Він виявляється у пізнавальній, аксіологічній діяльності національної мовної особистості, стереотипах їі поведінки - політичної і комунікативної» (Яремко 7). Вербальним утіленням національно-культурних, політичних особливостей постає комунікативна поведінка особисті в політичному дискурсі.

Упродовж становлення й розвитку фразеології як окремої мовознавчої галузі науковці вивчали процеси творення, механізми лексико-семантичної мотивації й функціонування фразеологічних одиниць (ФО) у різних лінгвокультурах. Цим дослідженням присвячені праці таких учених, як Л.Авксентьєв, О.Андрейченко Л. Булаховський, А. Емірова, О. Залевська, М. Ковшова та ін. Так, О. Селіванова розглядає мотиваційні процеси фразеологізмів російської мови на основі двовекторного підходу: від психокогнітивної моделі позначуваного до ономасіологічної структури найменування й навпаки. С. Коновець вивчає структуру образних ФО в періодичній пресі іспанських видань, більшість 3 яких має метафоричну основу. Зокрема, учена підкреслює, що когнітивний процес, який призводить до створення метафори, входить до ширшого 
процесу, тобто еволюції свідомості, забезпечуючи пізнання, освоєння культурного контексту, у якому через взаємодію 3 лінгвістичним оточенням виникають метафори (Коновець 7). Г. Степанова описує особливості породження фразеологічних одиниць у мовленні, типи їх можливих редукцій і трансформацій та стратегії продукування, способи зберігання $Ф 0$ в мовній свідомості. Дисертаційне дослідження О. Андрейченко присвячене лексико-фразеологічній основі політичних дискусій української преси кінця XX - початку XXI століття. Зокрема, дослідниця 3 метою виявлення характерних ознак концепту «влада» проводить психолінгвістичний експеримент, умовно розподіляючи реакції за трьома семантичними групами: а) структура влади; б) образні реакції, що виражають морально-етичну оцінку; в) метафоричні моделі. Серед образних реакцій виділяє пейоративні реакції, наприклад, представлені семантичними групами, які виражають негативну морально-етичну оцінку дій влади, що вербалізуються фразеологізмами добратися до владного корита; довгі руки влади тощо (Андрейченко 12-13).

Наведені роботи свідчать про підвищений інтерес до дослідження фразеологізмів у суспільно-політичних виданнях на матеріалі різних мов. На сучасному етапі розвитку лінгвістики повноцінне вивчення особливостей функціонування як узуальних, так і трансформованих фразеологізмів у політичному дискурсі неможливе без застосування здобутків суміжних галузей лінгвістики - психолінгвістики, когнітивної лінгвістики, прагмалінгвістики. Саме це визначає актуальність нашого дослідження.

Мета дослідження. Виявлення й опис комунікативної та прагматичної, структурно-семантичної характеристики особливостей функціонування фразеологізмів як засобів вираження емоційно-оцінних висловлювань у політичному дискурсі становить мету пропонованої роботи.

Матеріал і методи дослідження. Матеріалом дослідження було обрано фразеологізми української мови, що функціонують у суспільнополітичних виданнях сьогодення. У процесі вивчення фразеологізмів використовуються описовий метод, завдяки якому уможливлюється вивчення й опис різних типів фразеологічних значень на підставі семантичних і структурних показників; метод компонентного аналізу, завдяки якому виділяються інтегральні й диференційні семантичні ознаки в структурі фразеологічного значення. Метод дистрибутивного аналізу орієнтований на встановлення характеристик i функціональних властивостей фразеологічної одиниці із урахуванням їі оточення (дистрибуції). Емоційно-оцінні фразеологізми здатні забезпечити прагматичний ефект повідомлення, саме тому прагматичний аналіз передбачає вивчення стратегій і тактик впливу політиків, журналістів на адресатів за допомоги мовних, зокрема фразеологічних, одиниць.

Результати дослідження та дискусія. На підставі аналізу мовних фактів, точніше вживанні фразеологізмів з оцінним значенням, можна простежити стереотипні моделі сприйняття політичної дійсності 
українського суспільства. А. Емірова зазначає: «Фразеологія покриває переважно ті ділянки дійсності, які безпосередньо пов'язані з людиною, з їі баченням, оцінкою реалій, 3 психічними особливостями особистості пізнавальними процесами, емоційно-вольовою стороною психіки, індивідуально-типологічними особливостями особистості» тощо (29-30). Особливості політичного дискурсу відображаються у фразеології. Політичні реалії часто характеризуються використанням Ф0, що виражають позитивне або негативне ставлення до зображуваної події.

ФО в текстах суспільно-політичних видань виконують інформативну та експресивну функції, саме тому одним із домінантних чинників у формуванні семантичної цілісності фразеологічних одиниць $\epsilon$ оцінне значення. Політики, журналісти, використовуючи фразеологізми, дають власну (суб'єктивну) оцінку певної події, інформації з метою мовленнєвого впливу на аудиторію. ФО, як і мовні одиниці, часто використовують для маніпуляції суспільною свідомістю. І. Шкіцька підкреслює, що маніпулятивний вплив як спосіб зміни поведінки людини чи їі ментального чи емоційно-психічного стану характеризується емоційністю й оцінністю, які пов'язані між собою, і тому часто ототожнюються. Оцінка $є$ визначальною категорією, що лежить в основі тактики підвищення значимості співрозмовника (Шкіцька 382). У суспільно-політичному дискурсі активно функціонують як традиційні, так і трансформовані ФО, що характеризують явища, предмети, дії, відповідно мають позитивну або негативну конотацію.

В. Шаховський підкреслює, що знання про емоції формуються лінійно, поступово на основі особистісного, видового (соціального) досвіду й біологічної пам'яті. Вони включають у свою концептуальну структуру знання - рецептори (базові, однакові для семантичної пам'яті всіх комунікантів) і знання - ретуші, різні для різних комунікантів. I ті, й інші формують концептуальне значення лексикалізованої (вербалізованої) емоції у формі ментального конструкта (Шаховський 37). Тому фразеологізми, що називають або виражають ту або ту емоцію, у кодованій формі зберігають усі лінгвістичні й екстралінгвістичні знання про навколишній світ. Оцінка $є$ одним із основних способів відображення світосприйняття, культури суспільства.

Слід зазначити, що питання співвідношення емоції та оцінки на сьогодні $є$ дискусійним. Психолог К. Ізард емоції визначає як особливий психофізичний стан організму, що відображає ставлення людини до самої себе й оточення у формі інтенцій, безпосередніх переживань, відчуттів приємного чи неприємного, задоволення чи незадоволення, що обумовлюється відношенням об'єктивних властивостей світу до потреб і мотивів діяльності індивіда. В. Шаховський зазначає, що емоція - це форма оцінки суб'єктом об'єкту світу (8), тобто в основі емоції лежить оцінка, а кожна емоція людини є результатом певного виду оцінки. 
Поняття оцінки тісно пов'язане з вираженням емоційного ставлення людини до об'єкта висловлювання. Даючи оцінку, мовець передає своє позитивне або негативне ставлення за будь-якою ознакою. У структурі значення слова оцінка пов'язана передовсім з емоційним компонентом конотації (Бессонова 13). На думку О. Вольф, оцінка й емоція взаємодіють таким чином: 1) оцінка є думкою суб'єкта про цінність об'єкта для нього; 2) емоція є переживанням суб'єктом цієї думки (42). Отже, можна говорити про те, що вираження оцінки відображає емоційний стан мовця, який експліцитно вказує на позитивне або негативне ставлення до певної ситуації, проблеми, питання.

Оцінне значення науковці розглядають як філософську й лінгвістичну категорії. Зокрема, В. Корольова говорить про поступове формування оцінки як філософської категорії й виділяє такі її риси: 1) означає найзагальніше поняття «оцінка», що пов'язується з будь-яким предметом й ознаками дійсності; 2) $є$ бінарною, тобто розрахована на протилежні компоненти: позитивне - негативне; 3) кожен компонент бінарної пари характеризується градуальністю: більшою - меншою найменшою мірою; 4) містить поняття «норма», що $\epsilon$ історично змінне та національне забарвлене (5).

Як правило, оцінку в лінгвістиці розглядають як оцінний компонент лексичного значення. Такі спостереження $\epsilon$ досить закономірними, оскільки саме лексеми не лише номінують власне оцінні ознаки конкретних й абстрактних сутностей зовнішнього світу, а й передають інформацію про предмети, що є об'єктами мовленнєвої оцінки. Залежно від ознак, що актуалізуються під час оцінювання, підгрунтя оцінки зазвичай диференціюють на внутрішнє і зовнішнє. Внутрішнє відображає емоційну сферу мовця, його почуття, відчуття, позитивні й негативні емоції, пов'язані із психологічною сферою симпатії й антипатії. Зовнішньо орієнтоване на когнітивну сферу мовця, воно відображає знання суб'єкта, що формуються зв'язками ментальної й соціальної природи навколишньої дійсності (Вендина 45).

Оцінка як лінгвістична категорія виражає позитивне чи негативне ставлення мовця до змісту мовлення й реалізується в частинах слова, вигуках, модальних частках, повнозначних лексемах, словосполученнях, фразеологізмах, фразах, у мовленнєвих актах тощо. У складі цих мовних засобів оцінка входить до їхніх значень як ціннісний (аксіологічний) аспект, який може інтерпретуватися як «А (суб'єкт оцінки) вважає, що Б (об'єкт оцінки) поганий / гарний». Причому, оцінка постає універсальною лінгвістичною категорією, адже навряд чи існує мова, у якій відсутні поняття «гарно» та «погано» (Вольф 5).

На думку О. Арсентьєвої, «оцінний компонент, тобто схвальна або несхвальна оцінка, закладений у значенні фразеологізму, є основним у конотативному значенні ФО в силу його соціолінгвістичної природи. Суб'єктивно-оцінний елемент фразеологічного значення може бути 
пояснений диференційованою реакцією людей на позитивні й негативні явища і $є$ інтегральним у семантичній структурі Ф0» (40).

Лексичними маркерами емоційної оцінки є слова-компоненти $\Phi 0$, що виражають безпосередньо емоції, називають емоційний стан і / або емоційне ставлення. Наприклад ФО закласти міни: Досвід свідчить, що нічого доброго поспішний конституційний процес в умовах кризи і у форматі відвертого політичного торгу не обіцяє. Туди можуть закласти такі міни, що не виживе ніхто (Дзеркало тижня, 14.04.2014) (далі після цитати буде подано покликання на її джерело: видання та дату публікації матеріалу). Узуальний фразеологізм закладати / закласти підвалини (основи, фундамент) - «давати початок чому-небудь» (Словник 180) зазнає лексичних трансформацій - заміни слів-компонентів міни / фундамент, що призводить до виникнення іншого негативного значення, адже міна - це завжди щось небезпечне.

Дескрипторами загального плану називають «лексичні одиниці, що прямо не називають емоції, однак мають у значеннєвій структурі емотивну сему позитивної або негативної характеристики предмета, суб'єкта або поняття» (Будниченко 141). Легковажність витрачання грошей свідчить не лише про надмірну їх кількість, а й про несерйозність, необдуманість тих осіб, хто розпоряджається розподілом бюджету: Звіт палати свідчить, що кошти були розпорошені для задоволення місцевих забаганок на кшталт придбання ялинкових прикрас (Українська правда, 9.04.2019). Дієслівний компонент розпорошені реалізує додаткові семи «витратити марно», «розподілити на частини», відповідно підкреслює негативну оцінку цієї дії.

Із негативним забарвленням ужито трансформований фразеологізм любі французькі друзі. Саме іронічне прізвисько любі друзі групи помаранчевих соратників Віктора Ющенка символізує відданість другу і здатність у будь-який момент зробити якусь підлість, а також звинуватити в зраді національних інтересів. "Спільна дорожня карта», складена в Москві під час візиту двох франиузьких міністрів, - оборони та закордонних справ, - містить, слід розуміти, весь перелік путінських «хотєлок», на який пообіцяли зважати любі фрранцузькі друзі (Український тиждень, 19.09.2019).

У створенні оцінного ефекту важливу роль відіграють фразеологізми, що виконують не лише емоційно-експресивну функцію, але й прагматичну: вони впливають на думки й переконання, викликають певну психологічну й дієву реакцію адресатів. Вивчення фразеологізмів, що відображають експліцитно / імпліцитно певне оцінне значення, дозволяє зрозуміти узагальнену ціннісну орієнтацію суспільства на сучасному етапі його розвитку. Значення багатіти, наживатися (перев. нечесним шляхом) реалізує ФО «потрошити» банки, утворений шляхом субституції (пор.: набивати кишені) (Словник 314). Наприклад: Мабуть, тільки великий український бізнес зрадіє: зрозуміють, що, виявляється, $i$ 
тепер можна безкарно «потрошити» банки, а потім просто домовитися з тими двома з офісу (Дзеркало тижня, 21.09.2019).

Характерними ознаками політичного дискурсу слід уважати широту сфери функціонування, зверненість до актуальних проблем сьогодення, прагматичне та ідеологічне навантаження, а також оперування суспільнополітичною лексикою й фразеологією, що можуть піддаватися різним видам трансформації завдяки факторам екстралінгвістичної дійсності. Спостерігаємо використання таких видів трансформації, як субституція й розширення компонентного складу стоншувати сімейні бюджети; удар по гаманцях (пор. бити по кишені) (Словник 19). ФО реалізують синонімічне значення - «завдавати матеріальних збитків», відповідно відображають додаткове негативне значення, оскільки неможливість сплачувати значні суми за житлово-комунальні послуги свідчить про бідність, а також низький рівень життя суспільства сьогодення. Наприклад: Подорожчання не лише комуналки, а й інших товарів і послуг поступово стоншувало сімейні бюджети, що призвело до використання населенням заощаджень, накопичених у попередні роки; У період різкого підвищення житлово-комунальних тарифів вона допомогла згладити удар по гаманцях українців, які стрімко убожіють у кризовий період (Дзеркало тижня, 22.09.2018).

Антонімічне значення реалізує трансформований фразеологізм дощ із грошей пішов - «великі несподівані прибутки», відповідно реалізує позитивне оцінне значення, адже фінансові прибутки - це завжди добре. Компонент золото осмислюється як символ багатства, достатку, що у свою чергу пов'язано з уявленням про долю, успіх, благополуччя (Князь 50). Наприклад: Якщо в людей є гроші, якщо дощ із грошей пішов на всіх, то далі все починає працюват (Дзеркало тижня, 20.10.2019).

Стилістична різноманітність лексики є однією із характерних ознак політичного дискурсу. Цікавим $\epsilon$ використання фразеологізму вишенька на торті, що означає логічне завершення чого-небудь, тобто останній штрих. Завершальною стадією готування торта $\epsilon$ прикраса у вигляді вишеньки, що додає йому закінченості / досконалості. Слово-компонент торт реалізує значення приємної ситуації, однак контекстуальне оточення свідчить про негативну оцінку дії. В.Корольова підкреслює, що за допомогою контексту створюються умови для актуалізації оцінних сем, для переходу лексеми з потенційно раціональними оцінними семами до складу емоційних (30). Наприклад: Вишенькою на торті стала заява НКРЕКП про те, що діючий тариф на електроенергію для населення виявився «неринковим», і воно (населення) оплачує лише 42\% вартості (Дзеркало тижня, 10.02.2017).

Критерієм виникнення емоційної оцінки на фразеологічному рівні $\epsilon$ внутрішня форма ФО. Образ, покладений у внутрішній формі ФО, формується як прототип деяких властивостей, релевантних певному суспільству, призначений для класифікації виділених ознак з погляду 
відповідності оцінній нормі. Наприклад, функціонування ФО грошей кури не клюють. Щодо мотиваційної основи цього фразеологізму, то О. Селіванова підкреслює, що найпоширенішим типом мотивації фразеологізмів $\epsilon$ асоціативно-термінальний, що характеризується аналогізацією двох ментальних просторів, що інтегруються в особливий ментальний простір. Така інтеграція в сучасній когнітивній семантиці називається блендінг. Блендінг може здійснюватися шляхом синестезії образних уявлень, що надає фразеологізму експресивності, виразності (Селіванова 251). Наводимо ілюстрацію: Грошей кури не клюють: фіскальна служба підрахувала надходження 2017 року (Глос Черкащини, 04.01.2018). В основі образу фразеологізму лежить гіпербола; вона відштовхується від реальних побутових спостережень над курами, які відрізняються великою ненажерливістю й постійно клюють хоча б по зернятку. Якщо навіть кури виявляються пересиченими якою-небудь їжею, значить, її $\epsilon$ вдосталь. Отже, ФО грошей кури не клюють у свідомості людей сприймається й асоціюється із заможними людьми, у яких є надмірна кількість грошей, які, очевидно, нікуди дівати.

Особливістю фразеологізмів є єдність експресії й стандартного / типового, адже саме в політичному дискурсі ця єдність стає стилістичним принципом організації висловлення. Спостерігаємо використання ФО, до лексичного наповнення яких уходять слова-компоненти 3 різним стилістичним забарвленням: великі гроші, скажені гроші; живі гроші; шалені кошти. Зокрема, атрибутивні слова-компоненти шалені, скажені реалізують семи «які перевищують звичайну міру», «дуже великі», «незароблені», «отримані нечесним способом», «легко отримані». Відповідно фразеологізми мають негативне значення, оскільки саме такий спосіб заробляння грошей є неправильним у свідомості суспільства: $B u$ прийшли нам допомогти - чи все-таки заробити у нас скажені гроші? (Дзеркало тижня, 24.10.2019); «Навіть дурість держави часто коштує великих грошей» (Дзеркало тижня, 10.11.2017); Живих грошей ніхто не бачив, усе - у рахунок податків та інших платежів (Дзеркало тижня, 22.09.2018); Навіть на закупівлях ліків - попри війну - відмивалися шалені кошти (Дзеркало тижня, 10.02.2017).

Вибір лексики в політичному дискурсі впливає на емоційний стан адресантів. Публічне спілкування, у якому формуються й закріплюються негативні емоційні образи, породжує негативну психологічну атмосферу в суспільстві.

3 метою донесення інформації про прагнення неолігархічних партій зберігати посадовий рівень народний депутат Віктор Чумак використовує трансформований фразеологізм утриматися на політичній сцені (пор. узуальна ФО триматися на ногах - 1) «не втрачати здатності нормально рухатися, ходити, працювати і т.ін.; 2) «бути самостійним, упевненим, незалежним у своїх діях, вчинках») (Словник 713). У контексті ФО реалізує дещо інше значення «зберігати посадовий рівень, вистояти в трудній 
ситуації», що дає підставити говорити про те, що ФО піддається структурно-семантичній трансформації. Саме інтенції впливу на адресата в політичному дискурсі передбачають те, щоб «якомога повніше і швидше донести до соціуму важливий потік інформації, розтлумачити певні події, сформувати оцінку, активізувати та загострити увагу на необхідній інформації» (Шабат-Савка 296). Наприклад: Державне фінансування партій, контроль за використанням коштів, ефективні антикорупційні органи, роздержавлення ЗМI та створення натомість суспільних, лобіювання чесного виборчого закону і нової виборчої системи, ефективне державне врядування, політична реформа - це ініціативи, які за правильної реалізації дають неолігархічним партіям шанс утриматися на політичній сщені і розвиватися (Дзеркало тижня, 10.02.2017).

Висновки та перспективи досліджень. Отже, у політичному дискурсі використовують як узуальні, так і трансформовані фразеологізми, що зумовлено їхніми оцінними якостями та можливостями ефективного впливу на адресата. Прагматична роль трансформованих ФО виявляється в застосуванні ефекту новизни. Автори статей, політики удаються до лексичної заміни компонентів як однієї 3 важливих можливостей виявити потенційні функції ФО - посилення емоційності мовлення, вираження особистого ставлення до конкретної політичної ситуації, прагнення інтенсифікувати зміст, наявний в прямій номінації.

Функціонування фразеологізмів у політичному дискурсі засвідчує високий ступінь функціонально-стилістичної і комунікативнопрагматичної ефективності одиниць. Активне використання ФО у суспільно-політичному дискурсі пояснюється прагненням журналістів, політиків максимально точно, влучно охарактеризувати реалії політичного, культурного, соціального життя сьогодення. Емоційно-оцінні фразеологізми у політичному дискурсі слугують для здійснення ефективної комунікації, реалізуючи низку комунікативних функцій: повідомлення, експресії, впливу, аж до маніпулювання людською свідомістю.

Оцінка є універсальною категорією й характеризується ознаками, що актуалізуються фразеологізмами з різним емоційно-оцінним значенням. Ф0 відображають оцінне значення як імпліцитно, так і експліцитно, при цьому важливе значення має також i контекстуальне оточення, що впливає на фразеологізм. У політичному дискурсі превалюють фразеологізми, у значенні яких відображається несхвальна оцінка, оскільки характеризують ситуації, коли багатіють або наживаються на чомусь нечесним способом; коли завдають матеріальних збитків, що призводить до бідності населення, неможливості сплачувати навіть житлово-комунальні послуги. Використання ФО з різним стилістичний забарвленням вишенька на торті; потрошити банки; шалені гроші увиразнює мовлення, привертає увагу читача. 
Проте цим не вичерпується дослідження пропонованої теми, тому напрям подальших розвідок полягатиме в здійсненні комплексного аналізу фразеологічного матеріалу в політичному дискурсі з позицій психолінгвістики та когнітивної лінгвістики.

\section{Список використаної літератури}

Андрейченко, Оксана. Лексико-фразеологічна основа текстів політичних дискусій (на матеріалі української преси кінця XX - початку XXI століття). Автореф. дис. ...канд. філол. наук: 10.02.01. Київ, 2006.

Арсентьева, Елена. Сопоставительный анализ фразеологических единиц. Казань, 1989.

Арутюнова, Нина. «Дискурс». Лингвистический энщиклопедический словарь. Москва: Советская энциклопедия, 1990, с. 136-7.

Бессонова, О. Оцінка як семантичний компонент лексичного значення слова. Автореф. дис. ...канд. філол. наук: 10.02.19. Донецьк, 1995.

Будниченко, Л. «Смысловые функции эмотивных знаков препинания». Вестник СанктПетербургского университета. История, № 3, 2003, с. 140-3.

Вендина, Татьяна. «Семантика оценки и ее манифестация средствами словообразования». Славяноведение, №4, 1997, с. 41-8.

Вольф, Елена. Функциональная семантика оценки. Москва: Наука, 2006.

Изард, Кэррол. Психология емоций. Санкт-Петербург: Питер, 2008.

Князь, Тетяна. Фразеологізми української мови на позначення заможності: структурносемантичний, ідеографічний, лінгвокультурологічний аспекти. Харків: Точка, 2014.

Коновець, Сніжана. Комунікативно-прагматичні особливості актуалізації фразеологізмів у дискурсі сучасної преси (за матеріалами іспанських періодичних видань). Автореф. дис. ...канд. філол. наук: 10.02.05. Київ, 2002.

Корольова, Валерія. Оцінні найменування осіб у сучасній українській мові. Запоріжжя: Акцент Інвест-Трейд, 2012.

Селиванова, Елена. «Мотивационные процессы во фразеосистеме русского языка». Система і структура східнослов'янських мов. Київ: Знання України, 2003, с. 248-53.

Словник фразеологізмів української мови, уклад. В. М. Білоноженко, І. С. Гнатюк, В. В. Дятчук, Н. М. Неровня, Т. О. Федоренко. Київ: Наукова думка, 2008.

Степанова, Анна. «Психолингвистический подход к описанию фразеологических единиц русского языка». Вопросы психолингвистики, №1 (15), 2012, с. 124-33.

Шабат-Савка, Світлана. Категорія комунікативної інтенції в українській мові. Чернівці: Букрек, 2014.

Шаховский, Виктор. «Эмоции как объект исследования в лингвистике». Bonpocы психолингвистики, № 9, 2009, с. 29-42.

Шкіцька, I. «Оцінна лексика в маніпулятивній стратегії позитиву». Науковий часопис Національного педагогічного університету імені М. П. Драгоманова. Серія 10: Проблеми граматики і лексикології української мови, вип. 7, 2011, с. 382-7.

Яремко, Ярослав. Сучасна політична термінологія: на перетині когніції та комунікації. Дрогобич: Посвіт, 2015.

Эмирова, Адиле. Русская фразеология в коммуникативно-прагматическом освещении. Автореф. дисс. ...д-ра филол. наук. Ташкент, 1989.

\section{References}

Andreychenko, Oksana. Lexico-phraseological basis of political discussion texts (on the materials of the Ukrainian mass media, the end of 20-th - the beginning of the 21-st centuries). PhD Thesis Abstract. Kyiv, 2006. 
Arsent'eva, Elena. Sopostavitel'nyj analiz frazeologicheskih edinic. Kazan', 1989.

Arutjunova, Nina. "Diskurs". Lingvisticheskij jenciklopedicheskij slovar'. Moskva: Sovetskaja jenciklopedija, 1990, pp. 136-7.

Bessonova, 0. Otsinka yak semantychnyi komponent leksychnoho znachennia slova. PhD Thesis Abstract. Donetsk, 1995.

Budnichenko, L. "Smyslovye funkcii jemotivnyh znakov prepinanija". Vestnik SanktPeterburgskogo universiteta. Istorija, № 3, 2003, pp. 140-3.

Vendina, Tat'jana. "Semantika ocenki i ee manifestacija sredstvami slovoobrazovanija". Slavjanovedenie, no. 4, 1997, pp. 41-8.

Vol'f, Elena. Funkcional'naja semantika ocenki. Moskva: Nauka, 2006.

Izard, Carrol. The Psychology of Emotions. Sankt-Peterburg: Piter, 2008.

Kniaz, Tetiana. Frazeolohizmy ukrainskoi movy na poznachennia zamozhnosti: strukturnosemantychnyi, ideohrafichnyi, linhvokulturolohichnyi aspekty. Kharkiv: Tochka, 2014.

Konovets, Snizhana. Komunikatyvno-prahmatychni osoblyvosti aktualizatsii frazeolohizmiv $u$ dyskursi suchasnoi presy (za materialamy ispanskykh periodychnykh vydan). PhD Thesis Abstract. Kyiv, 2002.

Korolova, Valeriia. Otsinni naimenuvannia osib u suchasnii ukrainskii movi. Zaporizhzhia: Aktsent Invest-Treid, 2012.

Selivanova, Elena. "Motivacionnye processy vo frazeosisteme russkogo jazyka". Systema $i$ struktura skhidnoslovianskykh mov. Kyiv: Znannia Ukrainy, 2003, pp. 248-53.

Slovnyk frazeolohizmiv ukrainskoi movy, edited by V. M. Bilonozhenko, I.S. Hnatiuk, V. V. Diatchuk, N. M. Nerovnia, T. O. Fedorenko. Kyiv: Naukova dumka, 2008.

Stepanova, Anna. "Psycholinguistic Approach to the Description of Phraseological Units of the Russian Language ”. Journal of Psycholinguistics, no. 1(15), 2012, pp. 124-33.

Shabat-Savka, Svitlana. Katehoriia komunikatyvnoi intentsii v ukrainskii movi. Chernivtsi: Bukrek, 2014.

Shahovskij, Viktor. "Jemocii kak obekt issledovanija v lingvistike". Journal of Psycholinguistics, no. 9, 2009, pp. 29-42.

Shkitska, I. "Otsinna leksyka v manipuliatyvnii stratehii pozytyvu". Naukovyi chasopys Natsionalnoho pedahohichnoho universytetu imeni M. P. Drahomanova. Seriia 10: Problemy hramatyky i leksykolohii ukrainskoi movy, iss. 7, 2011, pp. 382-7.

Yaremko, Yaroslav. Suchasna politychna terminolohiia: na peretyni kohnitsii ta komunikatsii. Drohobych: Posvit, 2015.

Jemirova, Adile. Russkaja frazeologija $v$ kommunikativno-pragmaticheskom osveshhenii. Doctoral Thesis Abstract. Tashkent, 1989. 